\title{
Pengolahan Data Masuk dan Keluar Menggunakan PHP dan MySQL
}

\author{
Ikrar Panji Satrio', M. Dicky Firyal'², Syifa Irhammi Ramdhania3, Afriyani Agustin4, Aries \\ Saifudin ${ }^{5}$
}

Teknik Informatika, Universitas Pamulang, Tangerang Selatan, Indonesia, 15417 e-mail: 1ikrarpanji3@gmail.com, ${ }^{2}$ firyal1205@gmail.com, ${ }^{3}$ syifairhammi9@gmail.com, 4afriyaniagustin110499@gmail.com, ${ }^{5}$ aries.saifudin@unpam.ac.id

Submitted Date: April 06 ${ }^{\text {th }}, 2021$

Revised Date: July $05^{\text {th }}, 2021$
Reviewed Date: April $11^{\text {th }}, 2021$

Accepted Date: July $06^{\text {th }}, 2021$

\begin{abstract}
Many companies engaged in fashion and self-service such as Independent Jeans, still use manual processes in storing incoming and outgoing product data, and in the process the system is still inefficient and there may still be errors in storing incoming and outgoing product data. Such as the process of storing incoming and outgoing product data that still uses paper, and the calculations still use a calculator and product entry and exit transactions. So in order to solve this problem, we need a web-based application for processing incoming and outgoing product data that has login features, user lists, added users, supplier pages, brand management, SPG transactions, print transactions, print transactions, transaction lists, report pages. The development process uses the waterfall method, for the language it uses the PHP (HyperText Processor) programming language and MySQL as a DBMS. Application using the waterfall method can facilitate the process of completing the application development process because there are already stages in the method used.
\end{abstract}

Keywords: Information Systems; Waterfall; PHP; MySQL; DBMS

\begin{abstract}
Abstrak
Perusahaaan yang bergerak dalam bidang fashion dan swalayan seperti Independent Jeans, masih banyak yang menggunakan proses manual dalam penyimpanan data produk masuk dan keluar, dan dalam proses sistem tersebut masih kurang efisien dan kemungkinan masih ada kesalahan dalam penyimpanan data produk yang masuk dan keluar. Seperti proses penyimpanan data produk yang masuk dan keluar yang masih menggunakan kertas, dan perhitungannya masih menggunakan kalkulator dan transaksi masuk dan keluar nya produk. Maka untuk itu menyelesaikan permasalahan tersebut dibutuhkan sebuah aplikasi pengolahan data produk masuk dan keluar berbasis web yang memilik fitur login, list user, tambah user, halaman supplier, kelola brand, transaksi SPG, hasil cetak transaksi, cetak transaksi, list transaksi, halaman laporan. Proses pengembangannya menggunakan metode waterfall, untuk bahasanya menggunakan bahasa pemograman PHP (HyperText Processor) dan MySQL sebagai DBMS. Penerapan dengan menggunakan metode waterfall dapat memudahkan proses menyelesaikan proses pengembangan aplikasi karena sudah adanya tahapan-tahapan pada metode yang digunakan.
\end{abstract}

\section{Kata Kunci: Sistem Informasi; Waterfall; PHP; MySQL; DBMS}

\section{Pendahuluan}

Berkembangnya ilmu dan teknologi pada kehidupan manusia menjadikannya kebutuhan bagi manusia untuk memudahkan pekerjaan. Teknologi ditujukan untuk membantu berbagai jenis pekerjaan manusia untuk meningkatkan kemudahan, efektifas dan efesiensi (Taufiq, Magfiroh, Yusup, \& Yulianti, 2020). Teknologi informasi ditujukan untuk membantu pekerjaan dengan menyediakan informasi dan melakukan berbagai tugas yang berhubungan dengan pengolahan informasi (Hanum \& Saifudin, 2019). Manfaat itu dapat dimanfaatkan pada berbagai aspek, dalam hal ini juga dimanfaatkan pada proses penyimpanan data produk masuk dan keluar yang digunakan oleh SPG (Sales Promotion Girl). 
Dengan pemanfaatan ilmu dan teknologi tersebut maka hasilnya akan lebih akurat dan cepat dan dengan menggunakan pemanfaatan tersebut dapat mengurangi biaya serta penghematan waktu pengerajaan. Tentu dalam hal ini akan menjadi hal positif bagi para perusahaan maupun bagi konsumen.

Saat ini proses bagian SPG di sebagian perusahaan masih dilakukan secara manual menggunakan kertas. Dengan tidak adanya sistem informasi kejelasan tentang riwayat data produk masuk dan keluar di perusahaan tersebut dapat ditemukannya human error, dan menjadikan hal ini tidak efisien dan akurat.

Dengan demikian diperlukannya sebuah aplikasi pengelolahan data produk masuk dan keluar yang dapat memudahkan SPG atau perusahaan dalam proses pencatatan data produk masuk dan keluar. Dalam pencatatan yang masih serba manual sangat menyulitkan perusahaan dan SPG dalam memeriksa data produk yang masuk dan keluar. Oleh karena itu, penelitian ini mambuat rancangan sistem informasi pengelolaan data produk masuk dan keluar menggunakan PHP dan MySQL (Kadir, 2008). Pada pengembangan aplikasi dipilih menggunakan PHP dan MySQL atau berbasis web karena mudah perawatannya (Newman, 2001).

Tidak adanya informasi kejelasan tentang riwayat penyimpanan data produk masuk dan keluar di perusahaan akan ditemukannya human error dan menjadikan hal ini menjadi tidak efisien dan tidak akurat.

Penelitian ini membuat rancangan aplikasi pengelolaan data produk masuk dan keluar menggunakan model waterfall dikarenakan dengan model tersebut akan dapat memudahkan dalam tahap pengembangan karena dilakukannya secara bertahap.

\section{Metodologi}

Penelitian dimulai menggunakan metode observasi dan wawancara dengan perusahaan, mengamati secara langsung proses pencatatan data produk masuk dan keluar. Proses ini kami akan menggunakan metode waterfall.

Metode Waterfall ini dipilih karena metode ini yang paling mudah digunakan menurut kami. Metode waterfall ini memiliki 5 tahapan (Jogiyanto, 2005) yang nantinya akan dilakukan bertahap hingga selesai.

Requirement analysis and definition pada tahap ini kami menganalisa kebutuhan pengguna dan juga mengidentifikasi apa masalah yang dihadapi saat sedang melakukan proses pencatatan data produk masuk dan keluar. Kami mendapati masalah yang terdapat pada proses sebelumnya yaitu seperti proses pencatatan data produk yang masuk dan keluar masih menggunakan kertas, perhitungan menggunakan kalkulator dan transaksi pencatatan data produk masuk dan keluar masih ditulis pada buku hal ini kurang efisien karena dilakukan secara manual dan juga memungkinkan terjadinya kesalahan dalam proses input.

System and software design pada tahap ini, spesifikasi sistem dari kebutuhan pengguna yang didapat dari requirement analysis selanjutnya dianalisa kemudian diimplementasikan ke dalam bentuk desain pengembangan (Al Fatta, 2007). Pada tahap desain dapat dilakukan dengan membuat berbagai diagram yang menggambarkan rancangan aplikasi, salah satunya dapat digunakan diagram UML (Unified Modeling Language) (Fowler, 2005). Dari masalah yang ada kami mencoba untuk membuat sistem dengan desain yang dapat menampilkan produk yang masuk dan keluar dan nama brand. Sebelum membuat basis data, juga akan dilakukan analisa terhadap data yang akan disimpan/digunakan (Kursini, 2006). Analisa data meliputi fungsi, format, cakupan/jangkauan dan lainnya yang berhubungan dengan data.

Implementation and unit testing pada tahap ini rancangan aplikasi sistem diimplementasikan ke dalam bentuk rangkaian program dan pada tahap ini juga dilakukan pengujian dan pemeriksaan (Nugroho, 2003).

Integration and system testing tahap ini mengumpulkan semua rangkaian program menjadi keseluruhan kemudian program tersebut dilakukan pemeriksaan dan pengujian sistem sepenuhnya untuk mengetahui apakah masih ada error atau bug pada sistem tersebut. Pengujian software sebenarnya memiliki tujuan utama yang sederhana, yaitu untuk menjamin software yang dihasilkan sesuai dengan kebutuhan (requirement) yang ditetapkan sebelumnya (Maulana, Kurniawan, Keumala, Sukma, \& Saifudin, 2020). Pada penelitian ini akan dilakukan pengujian menggunakan metode Black Box. Pengujian Black Box yang memiliki arti bahwa pengujian ini hanya memeriksa suatu perangkat lunak dari hasil eksekusinya, tanpa harus tahu mengetahui kode program dan hanya memperhatikan fungsionalnya saja (Nugraha, Aditama, Arrofi, Ahmad, \& Yulianti, 2020). Kami mencoba menjalankan program tersebut dengan menggunakan aplikasi PHP. 
Operation and maintenance tahap ini merupakan tahap akhir, sistem yang sudah jadi dioperasikan oleh pengguna. Jika masih terjadi kesalahan yang terdapat pada sistem tersebut maka bisa diperbaiki oleh pengembang. Sejauh penggunaan aplikasi ini, program dapat digunakan dengan cukup baik.

Pada tahap ini dalam pengumpulan data kami menggunakan Metode Penelitian Lapangan (Field Research). Berikut teknik yang digunakan adalah:

a. Wawancara (Interview)

Pengumpulan data perdagangan dengan cara mengadakan tanya jawab langsung kepada SPG Independent jeans yang dapat memberikan penjelasan langsung ataupun data sebagai pelengkap penulisan ini.

b. Pengamatan (Observasi)

Tinjauan dan pengamatan yang dilakukan berkaitan dengan penelitian yang dilakukan di Independent jeans.

c. Penelitian Kepustakaan (Library Research) Penelitian kepustakaan kepustakaan dengan mempelajari literatur yang berkaitan dengan permasalahan yang dibahas. Dalam penulisan ini cara pertama yaitu melakukan pengamatan dengan cara membaca, mempelajari dan mengutip dari buku literatur serta sumber lain yang berkaitan dengan penulisan ini.

\section{Analisa Kelayakan}

Analisa kelayakan ini, kami lakukan analisa terhadap kelayakan program yang kami buat untuk dapat dijalankan dengan baik oleh pengguna. Proses yang masih manual sebelumnya akan dikerjakan dengan menggunakan proses dengan aplikasi kasir yang telah kami buat. Pada aplikasi yang kami buat akan memiliki fitur fitur login, list user, tambah user, halaman supplier, kelola brand, transaksi SPG, hasil cetak transaksi, cetak transaksi, list transaksi, halaman laporan. Dan semua fitur tersebut akan bisa diakses oleh pemilik ataupun kasir. Kami membuat aplikasi tersebut menggunakan sublime dan menjalankannya melalui aplikasi PHP dengan database MySQL.

\section{Hasil dan Pembahasan}

Selanjutkan desain yang telah dibuat diimplementasikan menggunakan bahasa pemrograman sehingga menjadi aplikasi yang dapat dieksekusi. Hasil dari penerapan metode/model sesuai desain dan metode ditunjukkan pada subbab berikutnya.

\subsection{Halaman Home}

Pada tampilan halaman home ini adalah halaman utama yang pertama kali muncul ketika membuka website tersebut.

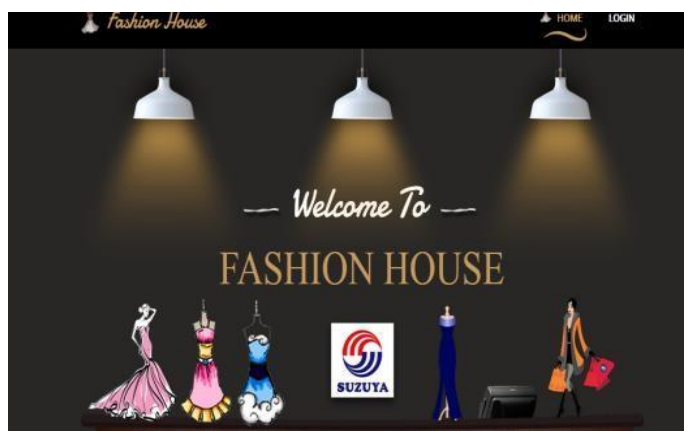

Gambar 1 Halaman Home

\subsection{Halaman Login}

Pada tampilan halaman login ini dapat digunakan sebagai pintu masuk oleh pengguna dalam mengelola dan menggunakan website tersbut. Tetapi harus memasukan Username dan Password terlebih dahulu.

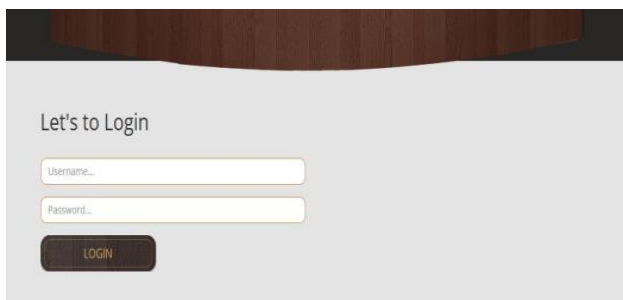

Gambar 2 Halaman Login

\subsection{Halaman List User}

Pada tampilan halaman list user ini merupakan halaman yang digunakan oleh pengelola dalam mengelola penggunaan seperti menambah, mengubah, dan menghapus data pengguna.

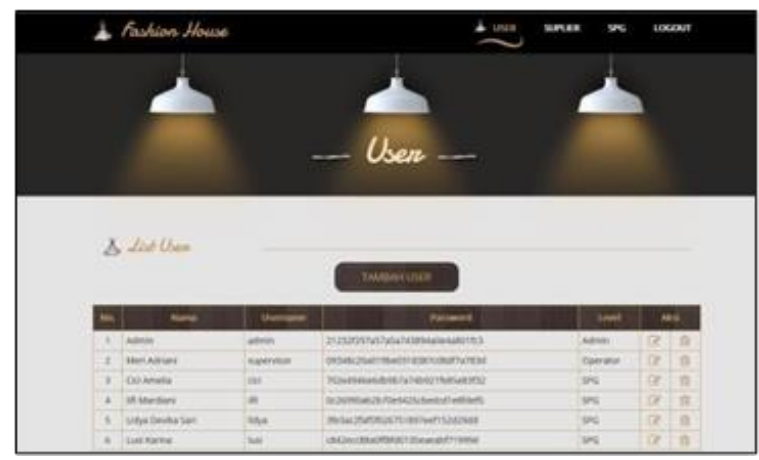

Gambar 3 Halaman list user 


\subsection{Halaman Tambah User}

Pada tampilan halaman tambah user ini merupakan halaman yang digunakan oleh pengelola untuk menambahkan user.

\section{User -}

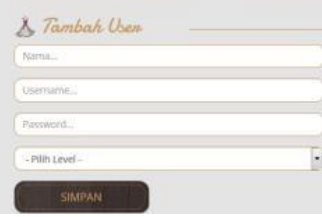

Gambar 3.4. Halaman Tambah User

\subsection{Halaman Suplier}

Pada halaman suplier ini merupakan halaman yang digunakan dalam mengelola data suplier, seperti menambah, mengubah, dan menghapus.

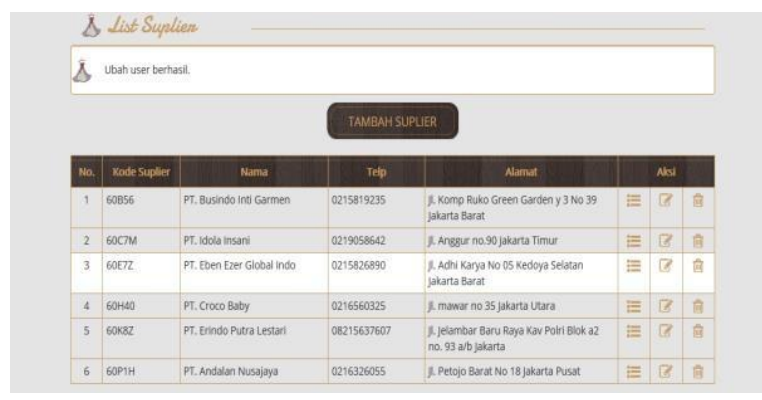

Gambar 5 Halaman supplier

\subsection{Halaman Kelola Brand}

Setelah sukses tambah suplier langkah selanjutnya pada kolom aksi mempunyai kelola brand, ubah, hapus. Kemudian dengan mengklik kelola brand maka akan muncul gambar tambah brand kemudian masukkan nama brand seperti gambar berikut:

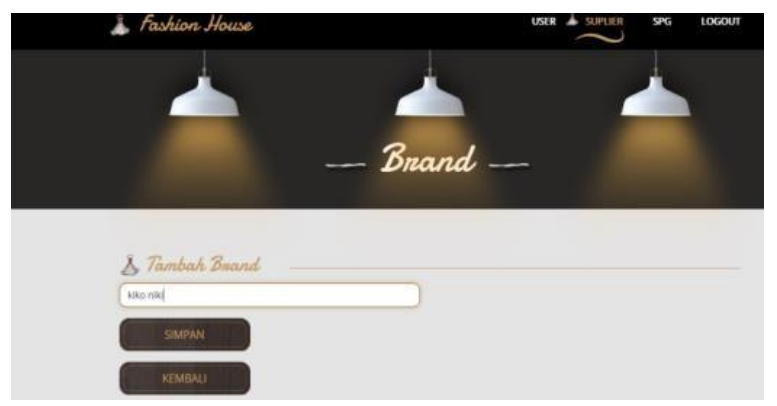

Gambar 6 Halaman Kelola Brand

\subsection{Halaman Transaksi SPG}

Halaman transaksi SPG menampilkan transaksi barang yang terjual berdasarkan brand yang dimiliki oleh SPG tersebut. Berikut adalah halaman transaksi SPG atas nama sisri yang memegang brand deline dan memasukkan nama brand, bulan, tahun sebagai berikut:

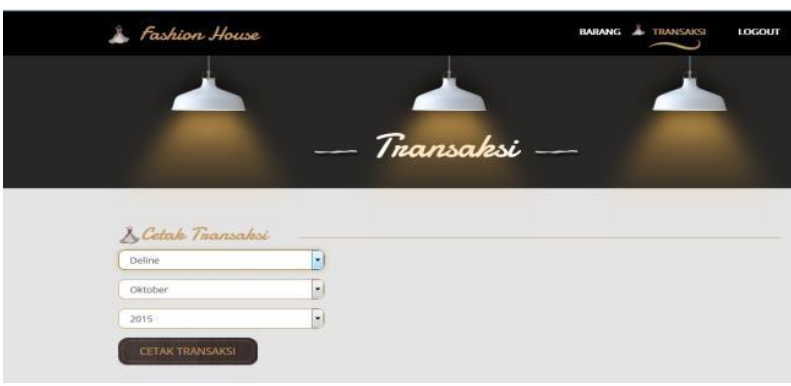

Gambar 7 Halaman transaksi SPG

Selanjutnya SPG juga dapat mencetak hasil dari transaksi tersebut dengan memilih bulan dan tahun kemudian mengklik tombol Cetak Transaksi, seperti hasilnya pada Gambar 8.

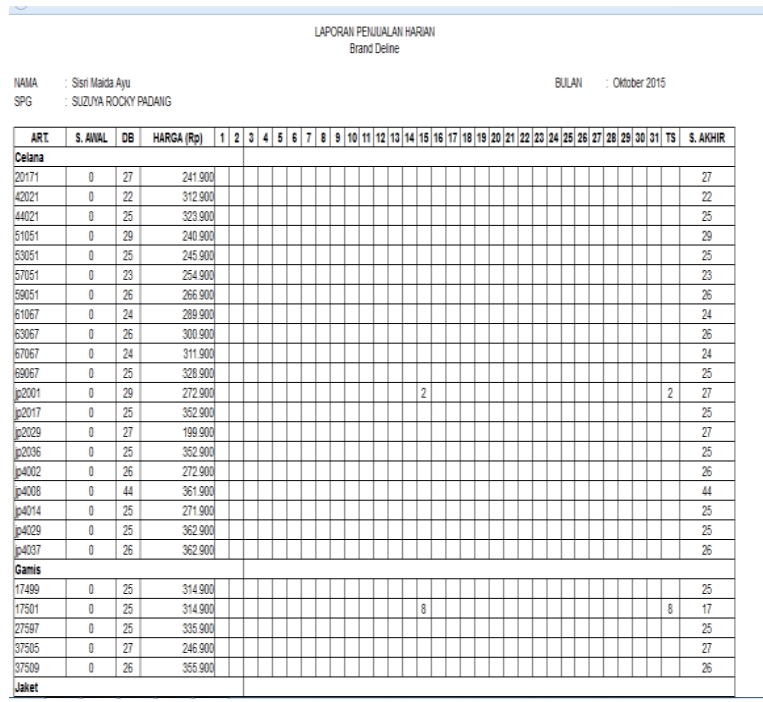

Gambar 8 Hasil cetak transaksi SPG

Berikut adalah halaman transaksi SPG atas nama sisri yang memegang brand kiko niki dan memasukkan nama brand, bulan, tahun sebagai berikut: 

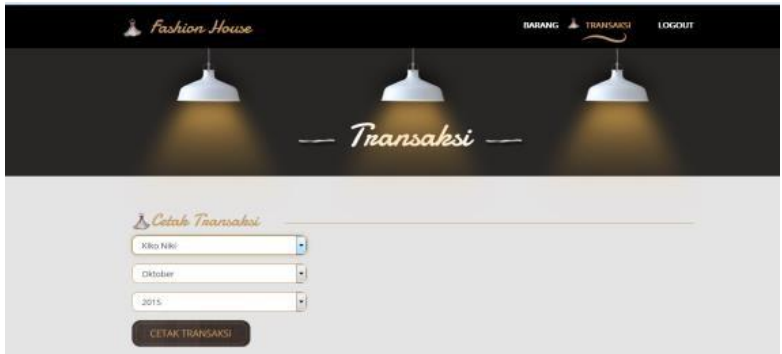

Gambar 9 Cetak Transaksi SPG

Selanjutnya SPG juga dapat mencetak hasil dari transaksi tersebut dengan memilih bulan dan tahun kemudian mengklik tombol Cetak Transaksi, seperti hasilnya pada gambar berikut.

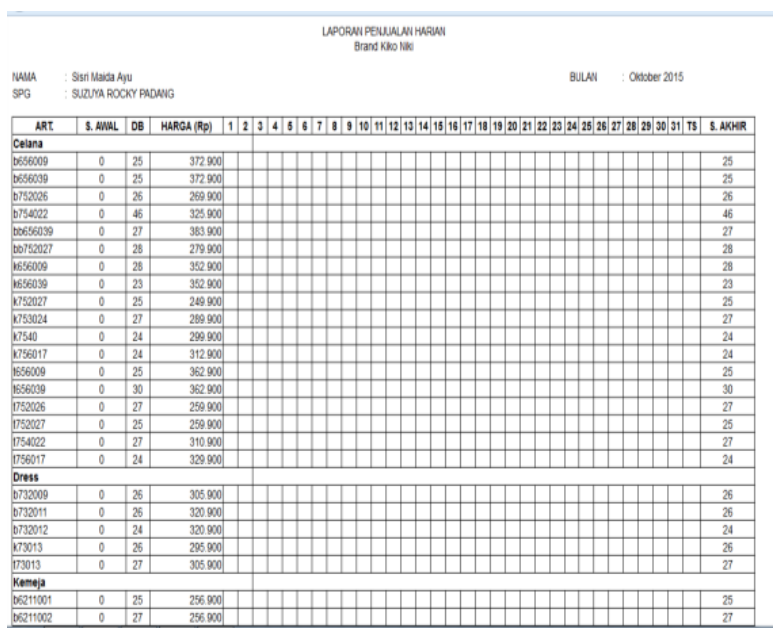

Gambar 10 Hasil cetak transaksi SPG

Halaman kasir merupakan halaman yang digunakan oleh kasir dalam proses transaksi penjualan barang. Selanjutnya kasir memasukkan username dan password kemudian dilanjutkan dengan mengklik login maka tampil seperti gambar berikut:

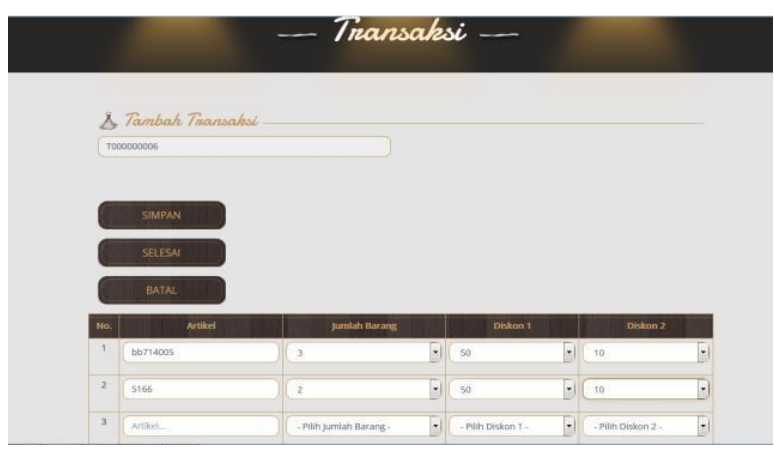

Gambar 3.11 Halaman Tambah Transaksi Kasir
Langkah selanjutnya dengan mengklik tombol tambah transaksi maka akan tampil gambar sebagai berikut:

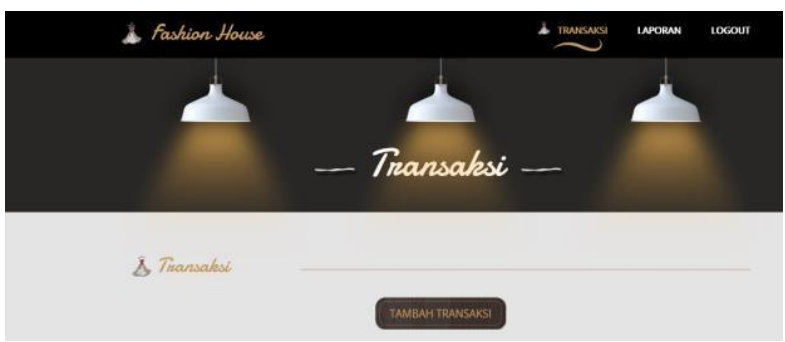

Gambar 3.12 Halaman transaksi kasir

Langkah selanjutnya, jika kasir sudah menekan tombol simpan dan selesai maka terdapat menu cetak transaksi, dimana memiliki kode transaksi, tanggal, kasir, barang, brand, jumlah, harga satuan, diskon, total harga (Rp), total harga jual (Rp) sebagai berikut:

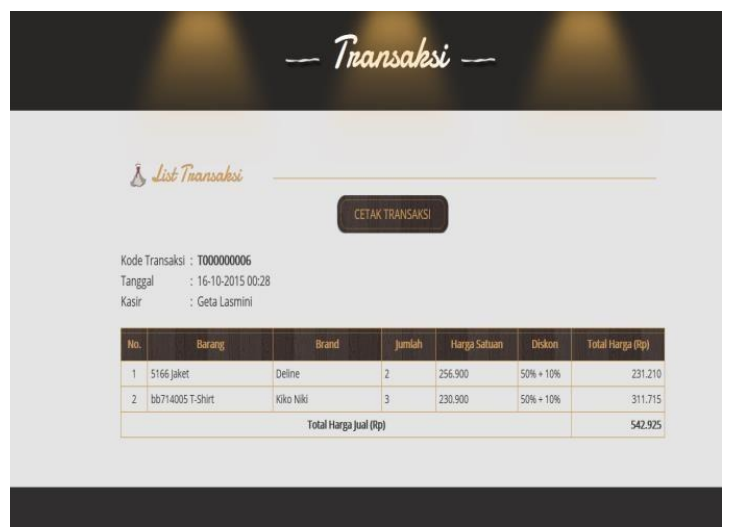

Gambar 3.13 Halaman List Transaksi

Selanjutnya dengan mengklik tombol cetak transaksi maka akan tampil halaman struk transaksi menampilkan kode transaksi, tanggal, kasir, no, barang, brand, jumlah, harga satuan, diskon, total harga (Rp), total harga jual (Rp). Di samping itu, kasir juga dapat mencetak struk transaksi.

\section{STRUK TRANSAKS}

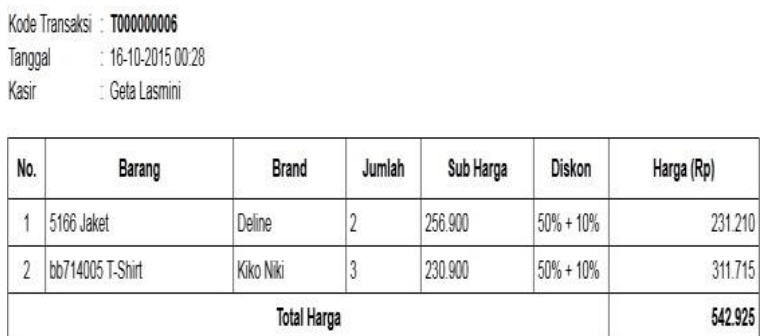

Gambar 3.14 Halaman Struk Kasir 


\subsection{Halaman Laporan Kasir}

Halaman laporan kasir menampilkan jumlah barang atau transaksi yang terjadi. Disamping itu, kasir juga dapat mencetak hasil transaksi yang dilakukannya dengan memilih bulan dan tahun yang akan dicetak.

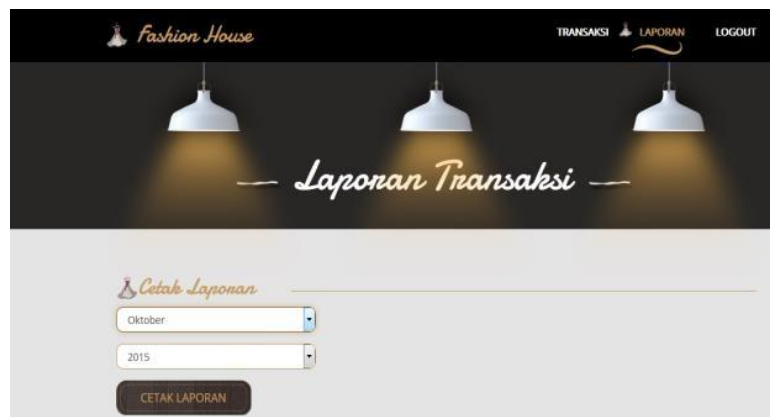

Gambar 3.15 Halaman Cetak Laporan Kasir

\section{Kesimpulan}

Kesimpulan berdasarkan dari analisa hasil penerapan metode untuk menyelesaikan masalah pada Aplikasi ini telah mampu menjawab pengelolaan dan administrasi dalam transaksi penjualan produk sebagai berikut :

a. Dari sisi pengelola, dapat memantau Supplier dan Brand apa saja yang tersedia, serta melihat SPG apa yang memegang brand tersebut.

b. Dari sisi SPG, mereka dapat memantau jumlah barang dari brand yang terjual, sehingga mereka menjadi lebih mudah dalam proses perhitungan barang.

c. Dari sisi kasir, mereka juga dapat dengan mudah barang-barang apa saja yang terjual melalui mereka.

\section{Referensi}

Al Fatta, H. (2007). Analisa dan Perancangan Sistem Informasi untuk Keunggulan Bersaing Perusahaan dan Organisasi Modern. Yogyakarta: Andi Offset.

Fowler, M. (2005). UML Distilled 3th Ed., Panduan Singkat Bahasa Pemodelan Objek Standart/Martin Fowler. Yogyakarta, Indonesia: C.V. Andi.

Hanum, W. S., \& Saifudin, A. (2019). Rancang Bangun Aplikasi Panduan Pariwisata di Kabupaten Banyuwangi Mobile Berbasis Android. Jurnal Teknologi Sistem Informasi dan Aplikasi, 2(2), 59-65. doi:10.32493/jtsi.v2i2.2798
Jogiyanto. (2005). Analisis dan Design Sistem Informasi Pendekatan Terstruktur dan Aplikasi Bisnis, Edisi Pertama Cetakan ke 4. Yogyakarta: C.V Andi.

Kadir, A. (2008). Belajar Database Menggunakan MySQL. Yogyakarta: Andi.

Kursini. (2006). Strategi Perancangan dan Pengelolaan Basis Data. Yogyakarta: Andi.

Maulana, A., Kurniawan, A., Keumala, W., Sukma, V. R., \& Saifudin, A. (2020). Pengujian Black Box pada Aplikasi Penjualan Berbasis Web Menggunakan Metode Equivalents Partitions (Studi Kasus: PT Arap Store). Jurnal Teknologi Sistem Informasi dan Aplikasi, 3(1), 50-56. doi:10.32493/jtsi.v3i1.4307

Newman, F. (2001). Pemrograman Client atau Server dengan ASP. Jakarta: PT. Elex Media Komputindo.

Nugraha, B. F., Aditama, F., Arrofi, M., Ahmad, S. U., \& Yulianti, Y. (2020). Pengujian Black Box pada Aplikasi Penghitungan Parkir Swalayan ADA Menggunakan Teknik Equivalence Partitions. Jurnal Informatika Universitas Pamulang, 5(2), 146-151. doi:10.32493/informatika.v5i2.5350

Nugroho, A. (2003). Analisis dan Perancangan Sistem Informasi dengan Metodologi Berorientasi Objek. Bandung: Informatika.

Taufiq, R., Magfiroh, D. A., Yusup, D., \& Yulianti, Y. (2020). Analisis dan Desain Sistem Informasi Pembayaran Sumbangan Pembinaan Pendidikan (SPP) di SMK Avicena Rajeg. Jurnal Teknologi Sistem Informasi dan Aplikasi, $\quad 3(1), \quad 15-21$. doi:10.32493/jtsi.v3i1.4308 